\title{
PRIMARY MATRIMONIAL REGIME AS REGULATED BY THE CURRENT ROMANIAN CIVIL CODE. MARRIAGE EXPENSES
}

\author{
M. G. Popescu
}

\section{Miron Gavril Popescu}

Faculty of Humanities and Social Sciences, Social Sciences Field

Aurel Vlaicu University of Arad, Arad, Romania

*Correspondence: Miron Gavril Popescu, Aurel Vlaicu University of Arad, Faculty of Humanities and Social Sciences, Elena Drăgoi Street, no. 2, post code 310330, University Complex M (Micălaca, zone III), Arad, Romania

E-mail: miron.popescu@yahoo.com

\begin{abstract}
:
Renouncing the binding nature of the legal matrimonial regime ${ }^{1}$, upon adoption of the new Civil Code, the Romanian lawmaker consecrated the patrimonial freedom of the spouses to decide as they deem appropriate and fit with regard to the property that is the object of their property relations.

The New Civil Code establishes the principle of the freedom of choice of the matrimonial regime, the future spouses having the choice to enter, outside the regime of the legal community of property (the only possible matrimonial regime according to the previous regulation of the Family Code), into a matrimonial convention, on the basis of which they shall "join" either the separation of property regime or the conventional community of property regime.

Regardless of the matrimonial regime chosen, whether legal or conventional, there is a common core of imperative, non-derogatory rules, which provide a minimal protection of the property relations between spouses.

The imperative primary regime is enshrined in the Civil Code in force, in Book II, About Family, Title II - Marriage, Chapter VI - Property Rights and Obligations of Spouses, Section 1 -Common Provisions, Paragraph 1 -About the General Matrimonial Regime (Art. 312-320), Paragraph 2 - The Family Dwelling (Art.321-324), Paragraph 3 - Marriage Expenses (Art.325-328).

In this article, the property obligations of the spouses present in the text of the law under the name of Marriage Expenses (Art. 325-328 Civil Code) are the subject of a legal review, highlighting a higher degree of concern on the part of the lawmaker, as compared to the current one, in drafting the Family Code, in terms of their regulation in relation to the accelerated dynamics of social relations.
\end{abstract}

Keywords: primary regime, marriage expenses, income from the profession, right to compensation, right to dispose, unwritten convention

\section{Introduction}

By virtue of the principle of unification of the legal rules governing the relations of private law, the new Civil Code reintroduces regulations of family law which, traditionally, are a part of civil law, not a separate branch of law.

\footnotetext{
${ }^{1}$ Under the Family Code, which was abrogated with the entry into force of the current Romanian Civil Code, the matrimonial regime of the spouses was that of the community of goods, unique, mandatory and immutable. For development, see Vasilescu, P. Regimuri matrimoniale. Partea generală (Matrimonial Regimes. The General Part), Rosetti Publishing House, Bucharest, 2003, page 258;
} 
By putting to use the allegations of the distinguished professor Jean Carbonnier ${ }^{2}$, according to whom the family is the oldest custom of mankind, the editors of the current code provide an approach of the legal institution connected to the new realities emerging in the field of family life, realities which in their turn justify their metamorphosis on the basis of two main sources. On the one hand, the evolution of the relationship between individual freedom and family interest has given rise to a greater independence of property for each spouse, and, on the other hand, a new interpretation in terms of the protection of the higher interest of the child has emerged.

It is in this line of thought that the legislative content of what the French doctrine ${ }^{3}$ referred to as the primary imperative regime (synonyms: basic property status, fundamental status, basic imperative status or primary matrimonial regime is enshrined in the Civil Code, Title II-Marriage, Chapter VI-Property Rights and Obligations of Spouses, Section 1 Common Provisions, Paragraph 1 -About the General Matrimonial Regime (Art. 312-320), Paragraph 2 -The Family Dwelling(Art. 321-324), Paragraph 3 -Marriage Expenses(Art. 325328).

In accordance with the assignment by the doctrine of an imperative nature, the lawmaker decided to regulate this regime, with certain exceptions, through rules of public order, stating, in Art. 312, para. (2) of the Civil Code, as follows: whatever the matrimonial regime chosen, the provisions of this section cannot be derogated from, unless the law provides otherwise.

It is imperatively necessary to mention that the primary matrimonial regime should not be confused with the legal matrimonial regime, the first being the species, and the second the genus, which make up one inseparable whole together. Thus, if civil legislation regulates the primary system as sole institution, which includes only mandatory legal provisions, the Romanian matrimonial regime has three different forms, of which the future spouses may choose one under the law, the primary regime applying to any marriage, together with the matrimonial regime chosen by the spouses.

While the primary system contains only provisions intended to provide a minimum protection of the property relationships established as a result of marriage, the legal matrimonial regime includes rules regarding the property of the spouses, their debts and the manner of managing them.

In addition to the legal tenets taken from the Family Code, the Civil Code of Quebec Province of Canada had a significant influence on the drafting of the new Romanian Civil Code.

As mentioned even by the Romanian lawmaker in the Memorandum of Reasons and in Decision no. 277 of $11^{\text {th }}$ March 2009 approving the Preliminary Theses of the Bill - the Civil Code, published in the Official Journal no. 213 of $2^{\text {nd }}$ April 2009, the recodification of Romanian civil law was achieved with the support of modern legislations, namely the Civil Code of Quebec Province, the French Civil Code, the Italian, Spanish, Swiss, German, Brazilian Civil Codes.

In accordance with these provisions, the Romanian lawmaker focused on the regulation and protection of family property ${ }^{4}$, as the mass of goods necessary to the household of the spouses. Thus, the Romanian Civil Code in force puts an emphasis on the family dwelling,

\footnotetext{
${ }^{2}$ Jean Carbonnier (1908-2003), the most important French jurist of the $20^{\text {th }}$ century, civil law specialist and professor of private law at the University of Poitiers (1937-1955), respectively Pantheon Assas University of Paris where he taught until 1976. His vision of law is influenced by realistic, skeptical and empirical elements of Protestant doctrine.

${ }^{3}$ Carbonnier, J. Les régimes matrimoniaux, $9^{e} e ́$ dition mise à jour, PUF, Paris, 1997;

${ }^{4}$ According to Art. 415 of the Code of the Province of Quebec, family property includes: the family residence or the rights conferred by the use thereof, the corresponding furniture, vehicles used to transport family members, pension rights accumulated during marriage.
} 
housing rights over the rented dwelling, acts of disposal that seriously threaten family interests, marriage expenses, institution which subsumes legal issues related to the contribution of the spouses (Art. 325), household work (Art. 326), income from the profession (Art. 327), the right to compensation (Art. 328).

In accordance with the provisions of Art. $325 \mathrm{New}$ Civil Code, spouses are obliged to provide material support for each other and contribute, depending on the means available to each of them, to the marriage expenses.

As already pointed out in the doctrine ${ }^{5}$, the analysis of the said text reveals the existence of two distinct obligations, the difference between them being an extremely fine one ${ }^{6}$. The first of the two, the obligation to provide material support for each other, confirms its belonging to the primary regime by the imperative nature of its wording. Like any rule of public order, it cannot be subject to any mitigation by way of matrimonial convention.

The second obligation, regarding the effective contribution to the family expenses- as a means of providing material support for each other- although included by the lawmaker in the public order core meant to govern the essential relations in a marriage, can be related to other criteria than the one mentioned in the law, by means of a matrimonial convention.

The limitation formulated by the legislator appears to be also derived from the mandatory nature of the primary regime. Although the amount of the contribution can be established by the parties to the convention, what cannot, however, be altered through the matrimonial convention is the common nature of these obligations, regardless of the matrimonial regime chosen. The sanction specific to the violation of this rule, by which a contractual clause would establish the unilateral obligation of one of the spouses to bear the family expenses and the exemption of the other spouse from this obligation, is deemed as unwritten (unwritten convention).

If the spouses do not decide how to allocate their expenditures between themselves, common law provisions in the matter shall be applicable, the amount of participation in the marriage expenses shall be established according to the means available to each of them.

Specifically, both the assets and the debts of each spouse shall be taken into account. The assets taken into account shall be assets owned individually, as well as assets owned by shares with the other spouse or with other persons, and assets owned jointly. Likewise, in determining the debt, one's own debt, as well as the joint debt with the other spouse or with other persons, shall be considered.

In the literature ${ }^{7}$, it has been considered that the participation of the spouses in the marriage expenses depending on the means available to each of them, even if contrary to the principle of equality between the two, is a rational and realistic legislative solution. On the contrary, the obligation of the spouses to contribute equally to the marriage expenses would mean, for the spouse who does not have the necessary means, to have an obligation that is excessively onerous and impossible to fulfill.

In conclusion, we can say that participation in the family spending is the only area of the imperative primary regime where spouses can manifest their right to derogate from the express reference of the law - namely, the means available to each of them - being allowed to establish the share of their contribution, regardless of their financial possibilities, without violating, thereby, any of the mandatory rules mentioned above.

Also, the amount of the execution of the obligation to participate in the marriage expenses may undergo certain fluctuations throughout the marriage of the spouses. At the

\footnotetext{
${ }^{5}$ Bacaci, Al., Dumitrache, C., Hageanu, C.C, Dreptul Familiei (Family Law), $7^{\text {th }}$ edition, C.H. Beck Publishing House, Bucharest, 2012, page 72;

${ }^{6}$ Bodoşcă T., Drăghici A., Puie I., Maftei I., Dreptul familiei (Family Law), Universul Juridic Publishing House, Bucharest, 2013, page 117;

${ }^{7}$ Bodoşcă T., Drăghici A., Puie I., Maftei I., op. cit., page 118;
} 
same time, depending on the specific possibilities applicable to each moment, the participation can be in the form of cash payments, in-kind contributions (provision of movable goods, food, ensuring the use of a building as family dwelling, etc.).

Art. 326 Civil Code provides, in the form of an express regulation, a solution proposed by the doctrine ${ }^{8}$ and enshrined by the legal practice ${ }^{9}$ related to the Family Code, establishing that the work of either spouse in the household and for child rearing is a contribution to the marriage expenses.

Once again, a single article of law establishes two distinct obligations for the spouses. As the content of the concept of household is not indicated by the provisions of civil legislation, by resorting to the Explanatory Dictionary of the Romanian Language, we can say that the household means all the goods which make up the movable and immovable property of a person or family, or the unit consisting of a dwelling and the persons who live together on its premises ${ }^{10}$.

Child rearing is, according to the provisions of the Civil Code, an obligation derived from the provisions established by the Constitution of Romania, in Art. 48, para. (1), the family is founded on the freely consented marriage of the spouses, their full equality, as well as the right and duty of the parents to ensure the upbringing, education and instruction of their children. The wording of the fundamental law indicates, in relation to the parents' obligation, the absolute right of the unmarried minor child to benefit from the conditions necessary for his/her harmonious physical and mental development. Thus, Art. 326 Civil Code imposes as a rule of the imperative primary regime from which the spouses cannot derogate through a matrimonial convention, the obligation to do consisting in the care, surveillance, support and education of their unmarried minor children. These provisions have an impact on the partition action, in establishing the shareable mass.

Art. 327 New Civil Code provides, in accordance with Art. 57 of the fundamental law ${ }^{11}$, the right of each spouse to freely exercise a profession and to use as he/she finds fit the income earned, on condition of having fulfilled his/her obligations in the context of the marriage expenses.

Given the many controversies arisen in the doctrine as regards the content of the concept right to dispose, we shall consider as follows, joining the views already expressed in the literature ${ }^{12}$, that it should not be understood as an attribute of the ownership right, but as a prerogative of the holding spouse which cannot be challenged by the other spouse. Thus, the spouse holding these rights may use them, while respecting public order and morality, as general limits of the exercise of any rights or freedoms (Art. 14, para. 1 of the Civil Code), and also respecting the obligations he/she has regarding marriage expenses, as special limits (Art. 327 Civil Code).

As regards the income earned, this phrase must be interpreted depending on the actual matrimonial regime in a specific case.

If marriage is under the matrimonial regime of legal community, the provisions of Art. 327 shall be concurrent with those of Art. 341, income from work, amounts due as social

\footnotetext{
${ }^{8}$ Filipescu, I.P, Filipescu, A.I, Tratat de Dreptul Familiei (Family Law Treatise), $7^{\text {th }}$ edition, Universul Juridic Publishing House, Bucharest 2007, page 69;

${ }^{9}$ For details, see the Supreme Court, Civil Division, Decision no. 730/1980, in the Collection of Decisions (CD) 1990, page 22;

${ }^{10}$ See the Explanatory Dictionary of the Romanian Language (DEX), page 429;

${ }^{11}$ Romanian citizens, foreign citizens and stateless persons shall exercise their constitutional rights and freedoms in good faith, without any infringement of the rights and freedoms of others, Art. 57 of the Constitution. Thus, specifically, a restriction may be ordered by law. It is also worth mentioning the restriction of the exercise of certain rights on the basis of a criminal judgment of conviction of one of the spouses and the enforcement of a complementary sanction. See Art. 66 of the New Criminal Code;

${ }^{12}$ Bodoaşcă T., Drăghici A., Puie I., Maftei I., op. cit., page 120;
} 
security pension and the like, as well as the income due under an intellectual property right are common property, regardless of their acquisition date, but only if the claim for their collection becomes due during the community.

Given that the rule stipulated by Art. 341 is a special rule, as compared to the one stipulated by Art. 327, which is a general one, according to the principle specialia generalibus derogant (special departs from general), the income earned by one of the spouses during legal community, including income resulting from the exercise of his/her profession, being commons property, is subject, as regards the acts on conservation, use and management, to Art. 345 para. $2^{13}$. On the other hand, alienation and encumbrance acts are subject to the provisions of Art. 346 Civil Code, as follows: acts of alienation or encumbrance of real rights covering common goods cannot be concluded without the consent of both spouses.

In the case of the matrimonial regime of the conventional community, the special, derogatory, provisions of Art. 341 can only be incident where the spouses do not decide otherwise by matrimonial convention. In this regard, the provisions of Art. 368 Civil Code are unambiguous, to the extent that it is not provided otherwise by matrimonial convention, the legal regime of conventional community is completed by the legal provisions regarding the legal community regime.

In the context of the matrimonial regime of the separation of property, the common right established by the principle stated in Art. 327 is incident, because in the case of this type of regime there is no concurrence between general and special rules.

By virtue of the material support obligation imposed by Art. 325 para. (1), one of the spouses can support financially the other spouse in initiating or carrying out a professional activity. In case of surpassing the limits of the obligation of material support or contribution to the marriage expenses, a right to compensation of the other spouse is born.

The specialized literature has considered this situation as a sui generis case of unjust enrichment.

For the emergence of a right to compensation, three conditions must be met cumulatively: there should be an effective participation of a spouse in the professional activity of the other spouse, by acts and deeds belonging to the content of the duties or activities imposed by the profession practised by the spouse.

The second condition is that participation should exceed the limits of the legal obligations of material support and contribution to the marriage expenses, and the last requirement indicates the lucrative nature, of unjust enrichment, as a result of carrying out the respective professional activity. From this latter condition we can conclude that the spouse in question did not participate in the professional activity of the other spouse pursuant to a legally binding onerous act concluded with the other spouse or another person, but for the benefit of the latter.

What the legal text does not specify is at which time can the right to this compensation be exercised, whether it could be claimed during the marriage, or just upon liquidation of the matrimonial regime.

\section{Conclusions}

In the context of the new regulations, it can be seen, from a first analysis, there is an increased concern on the part of the lawmaker for the standardization of the property rights and obligations of the spouses, on the one hand, through a broader and more thorough regulation of the patrimonial effects of marriage (61 articles, from 312 to 372 of the Civil

\footnotetext{
${ }^{13}$ Art. 345 para. (1) Each spouse has the right to use the common good without the express consent of the other spouse.

(2) Also, each spouse may enter into single acts of conservation, acts of management on any of the common goods.
} 
Code, being dedicates to this field, unlike the Family Code which only reserves 8 articles for it), and on the other hand, through the regulation of certain new aspects: the conventional mandate and the judicial one (Art. 314-315 New Civil Code), the patrimonial independence of the spouses (Art. $317 \mathrm{New}$ Civil Code), the income from the profession (Art. $327 \mathrm{New}$ Civil Code), the preciput clause (Art. 333 New Civil Code), etc.

Although the lawmaker puts an emphasis on the freedom of choice of the spouses by providing a plurality of matrimonial regimes, under the imperative of legal protection, it does, however, limit their freedom by establishing a core of non-derogatory rules, the primary regime, applicable to any matrimonial regime. Regardless of the matrimonial regime chosen by the spouses, the purpose of the existence of such a set of legal rules is to provide rules of public order intended to protect the essential relationships in a marriage, in normal situations, as well as crisis situations.

The lawmaker has thus expressly enshrined, as a distinct sub-chapter, marriage expenses, a legal institution subjected to a thorough analysis in this article.

\section{Bibliography:}

1. Avram M., Nicolescu C., Regimuri matrimoniale (Matrimonial Regimes), Hamangiu Publishing House, Bucharest, 2010;

2. Bacaci Al., Dumitrache V.C., Hageanu C.C., Dreptul familiei (Family Law), $4^{\text {th }}$ edition, All Beck Publishing House, Bucharest, 2005;

3. Bacaci Al., Raporturile juridice patrimoniale în dreptul familiei (Patrimonial Legal Relations in Family Law), $2^{\text {nd }}$ edition, Hamangiu Publishing House, Bucharest, 2007;

4. Bacaci Al., Dumitrache V.C., Hageanu C.C., Dreptul familiei în reglementarea noului Cod Civil (Family Law under the Regulation of the New Civil Code), $7^{\text {th }}$ edition, C.H. Beck Publishing House, Bucharest, 2012;

5. Bacaci, Al. Corelaţia prevederilor legale referitoare la obligaţiile comune ale soților $\mathrm{cu}$ cele privind drepturile lor asupra bunurilor comune(Correlation Between the Legal Provisions on the Joint Obligations of the Spouses and Those Regarding Their Rights over Common Property), R.R.D. no. 6/1986;

6. Banciu A. Al. Raporturile patrimoniale dintre soţi potrivit noului Cod civil, (Patrimonial Relationships Between Spouses under the New Civil Code), $1^{\text {st }}$ and $2^{\text {nd }}$ edition, Hamangiu Publishing House, Bucharest, 2011;

7. Banciu, A. Al., Unele aspecte ale raporturilor patrimoniale dintre soţi reglementate pentru prima oară ca instituţii juridice de noul Cod Civil (Some Aspects of the Patrimonial Relations Between Spouses Regulated for the First Time as Legal Institutions by the New Civil Code) in the journal Fiat Justitia, no. 2/2010 of Dimitrie Cantemir Faculty of Law, ClujNapoca, Argonaut Publishing House, Cluj-Napoca, 2010;

8. Bodoşcă T., Drăghici A., Puie I., Maftei I., Dreptul familiei (Family Law), Universul Juridic Publishing House, Bucharest, 2013;

9. Dobre A.F., Convenţiile şi regimurile matrimoniale sub imperiul noului Cod Civil (Conventions and Matrimonial Regimes under the Rule of the New Civil Code), in Dreptul (Law) no. 3/2010;

10. Filipescu, I.P, Filipescu, A.I, Tratat de Dreptul Familiei (Family Law Treatise), $7^{\text {th }}$ edition, Universul Juridic Publishing House, Bucharest 2007;

11. Florian E., Dreptul Familie în reglementarea noului Cod Civil (Family Law under the Regulation of the New Civil Code), $4^{\text {th }}$ edition, C.H. Beck Publishing House, Bucharest, 2011;

12. Hageanu, C.C. Dreptul familiei şi actele de stare civilă (Family Law and Civil Status Documents), Hamangiu Publishing House, Bucharest, 2012; 
13. Imbrescu, I., Tratat de dreptul familiei (Family Law Treatise), Lumina Lex Publishing House, Bucharest, 2006;

14. Turianu C., Dreptul Familiei. Practică judiciară comentată şi adnotată (Family Law. Legal Practice Commented and Annotated), Pinguin Book Publishing House, Bucharest 2004;

15. Roşu C., Necesitatea revenirii la liberatea convenţiilor matrimoniale (The Need of Recovering the Freedom of Matrimonial Conventions), in Dreptul (Law) 7/1999;

16. Uliescu, M, Noul Cod Civil. Comentarii (The New Civil Code. Comments), third edition revised and expanded, Universul Juridic Publishing House, Bucharest, 2011;

17. Vasilescu, P. Regimuri matrimoniale. Partea generală (Matrimonial Regimes. The General Part), Rosetti Publishing House, Bucharest, 2003. 